\title{
OBITUARY: Claudio Frigerio
}

Claudio Frigerio, who died suddenly last spring, was among the early members of the Italian Archaeological Mission's teams in Libya under Professor Sandro Stucchi. Since he would sometimes stay on after his colleagues had returned home in order to complete technical undertakings, he became very much part of the Cyrenaican scene; and has, for some years, been closely connected with Stucchi's project for the restoration of the Temple of Zeus at Cyrene. He was a talented draftsman and an archaeological technician of skill, who also had a great ability to communicate. That was true in the most obvious sense, for his command of Arabic was a wonderful help in a crisis; but also in subtler ways, since to those who took coffee with him in his 'apartment' at Shahat his conversation would bring lively insights, derived from his perceptive knowledge of Cyrene, its modern inhabitants and its surrounding country, all of which he knew well. In another mood he was a keen fisherman and could make splendid barbecues with his catch. In my recollection he seems always to have been able to find something in any situation in which to take a faun-like delight, and was always kind. He will be sadly missed in Cyrene and in the study of Cyrenaean archaeology.

Joyce Reynolds

\section{OBITUARY: Charles Daniels}

When the Corbridge Training Excavation was running near Hadrian's Wall in the late 1950s a figure dressed in a thick North-African overcoat and matching clothes could often be seen walking to an evening meal at one of Corbridge's hostelries. These two influences, the archaeology of Africa and Hadrian's Wall, were to dominate the academic life of Charles Daniels.

After developing an interest in history in his native Newcastle he moved to his home University where he was to stay for the rest of his life as a teacher and museologist. On graduation he completed an MA in Mithraic Studies, another 'leitmotif' along his academic path. His presence at Newcastle then led to a position as Director of excavations at the Red House Baths near Corbridge, an interest in Roman thermae that was intended to broaden into a doctorate that fell away with the transfer of his supervisor, the late Sir Ian Richmond, to Oxford. By this time he had already been introduced to the rigours of North African, and specifically Libyan, archaeology through his colleague Dr David Smith with whom he made initial trips to southern Tripolitania and the Fezzan. In 1960 a period of research at the British School in Rome also acted as a springboard for further work in Libya. At the time the then Director stated that he "had best get the desert out of his system while still a young man' but Charles persisted in developing a major programme of work on the archaeology of the Fezzan, the potential of which had first been revealed (with the aid of a military escort) by the Italian archaeologist, Giacomo Caputo, before the onset of the Second World War. From 1964 into the early 1970s Charles conducted survey and excavation in the Wadi el Agial, the heartland of the Garamantian kingdom, aided by a team of volunteers drawn from the archaeologists of the northern frontier and the indefatigable support of his wife Miriam. The programme saw the establishment of a firm chronology of the early Garamantian capital of Zinchechra, capping the rocky promontory that looked down on the later capital of Germa (Garama). The archaeological evidence that Daniels gathered from this area appeared in articles in The Antiquaries Journal and a book on the Garamantes under the Oleander imprint. 